\title{
Perineal leiomyoma in a postmenopausal woman: A case report
}

\author{
YAN-XIA SUI ${ }^{1,2^{*}}$, CHAO SUN $^{1 *}$, SHU-LAN LV $^{1}$, NASRA BATCHU ${ }^{1}$, JUN-KAI ZOU $^{1}$, \\ JIANG DU ${ }^{1}$, QING SONG ${ }^{1,3}$ and QI-LING LI ${ }^{1}$ \\ Departments of ${ }^{1}$ Obstetrics and Gynecology and ${ }^{2}$ Pathology, First Affiliated Hospital, Xi'an Jiaotong University, Xi'an,
Shaanxi 710061, P.R. China; ${ }^{3}$ Cardiovascular Research Institute, Morehouse School of Medicine, Atlanta, GA 30310, USA
}

Received April 6, 2015; Accepted June 2, 2016

DOI: $10.3892 / \mathrm{ol} .2016 .4830$

\begin{abstract}
Leiomyomas in the female reproductive system are commonly located in the uterus and typically regress following the menopause. Vulval leiomyomas are rare, and to the best of our knowledge, perineal leiomyomas in postmenopausal women have not been previously reported in the literature. The present case describes a 60-year-old Chinese woman who experienced perineal tenderness and lumbosacral radiating pain. The patient, who went through the menopause 12 years previously, had presented with a painful perineal mass for 1 year, which was subsequently diagnosed as a postmenopausal perineal leiomyoma. The mass was locally resected, and histopathological examination of the lesion resulted in a diagnosis of benign epithelioid leiomyoma. Immunohistochemical staining identified that the leiomyoma was positive for estrogen receptor and negative for progesterone receptor expression. The patient was followed up for 1 year and did not experience any pain or recurrence. The symptoms of local and lumbosacral radiating pain are extremely rare and may be induced by peripheral nerve stimulation. The etiology of postmenopausal perineal leiomyoma may be associated with infection, dietary, stress and environmental factors, and the role of estrogen cannot be overemphasized in cases of postmenopausal leiomyoma.
\end{abstract}

\section{Introduction}

Leiomyomas are benign, soft tissue tumors that originate from smooth muscle and account for $\sim 3.8 \%$ of all benign soft tissue tumors (1). The most common gynecological leiomyoma is uterine leiomyoma. The exact causes underlying the development of these lesions are not known. Uterine leiomyomas are speculated to be hormonally responsive neoplasms, and it has been suggested that estrogen and progesterone may stimulate

Correspondence to: Dr Qi-Ling Li, Department of Obstetrics and Gynecology, First Affiliated Hospital, Xi'an Jiaotong University, 277 Yanta West Road, Xi'an, Shaanxi 710061, P.R. China

E-mail: liqiling@mail.xjtu.edu.cn

${ }^{*}$ Contributed equally

Key words: leiomyoma, perineum, postmenopause susceptible uterine fibromuscular elements. The expression of progesterone receptor (PR) and estrogen receptor (ER) is significantly increased in the tissues of uterine leiomyoma (2). Vulval leiomyomas primarily develop in premenopausal women and usually occur in the clitoris, and labia majora and minora (3). As for premenopausal perineal leiomyoma, only 3 cases have been reported in the literature (Table I). To the best of our knowledge, there are currently no cases describing the presence of perineal leiomyomas in postmenopausal woman.

The present case describes a postmenopausal woman who presented with tenderness, lumbosacral radiating pain and a perineal mass, which was eventually diagnosed as a hormone-independent perineal leiomyoma. The discussion of the case is followed by a brief review of the available literature.

\section{Case report}

A 60-year-old Chinese female (gravida 4, para 4) was admitted to the Department of Gynecology, First Affiliated Hospital, Xi'an Jiaotong University (Xi'an, China) in May 2014 after experiencing perineal tenderness for the last year, in addition to lumbosacral radiating pain, which occurred 6 months previously. The patient had a history of surgical sterilization and went through the menopause 12 years previously. The patient had no history of hormone replacement treatment. During physical examination, palpation identified a movable, tender, hard mass $(\sim 1 \times 1 \times 1 \mathrm{~cm})$ that extended from the rear of the left labia majora to the frenulum of the labia minora near the anus. Doppler ultrasonography of the uterus and uterine adnexa was considered satisfactory for the patient's age. It was decided that local mass resection would be performed. During surgery, a solid and well-demarcated mass was removed without invasion of the surrounding tissues. Histopathological analysis confirmed the presence of a benign perineal leiomyoma (Fig. 1). Immunohistochemical staining with antibodies against ER and PR identified that the lesion was positive for ER expression (+2, 40\%) (Fig. 2) and negative for PR (Fig. 3). The patient was followed up for 1 year with no recurrence, pain or fecal incontinence.

\section{Discussion}

Leiomyomas, which are typically hormone sensitive, develop most commonly in females during their reproductive years and often regress following menopause (4). Only 1 case of vulval 
Table I. Summary of perineal leiomyoma cases in the literature.

\begin{tabular}{lcccccc}
\hline Author, year & Age, years & Mass and symptoms & Menopausal & Pathology & Prognosis & Refs. \\
\hline $\begin{array}{l}\text { Roy et al, } \\
1998\end{array}$ & 47 & $\begin{array}{l}\text { Palpable soft, cystic } \\
\text { masses in the vulva and } \\
\text { perineum with no pain }\end{array}$ & No & $\begin{array}{c}\text { Negative for } \\
\text { malignant cells }\end{array}$ & $\begin{array}{c}\text { No recurrence } \\
\text { in 2 years }\end{array}$ & $(14)$ \\
$\begin{array}{l}\text { Koc } \text { et al, } \\
2010\end{array}$ & 47 & $\begin{array}{l}\text { Palpable solid, cystic } \\
\text { mass with a painless } \\
\text { perineal swelling }\end{array}$ & No & N/A & $\begin{array}{c}\text { No recurrence } \\
\text { in 1 year }\end{array}$ & (15) \\
$\begin{array}{l}\text { Oliveira Brito et al, } \\
\text { 2011 }\end{array}$ & 36 & $\begin{array}{l}\text { Palpable soft, cystic mass } \\
\text { with perineal tenderness } \\
\text { and local pain }\end{array}$ & No & $\begin{array}{c}\text { Benign } \\
\text { mesenchymal } \\
\text { tumor }\end{array}$ & No recurrence & (1) \\
\hline
\end{tabular}

N/A, not available.

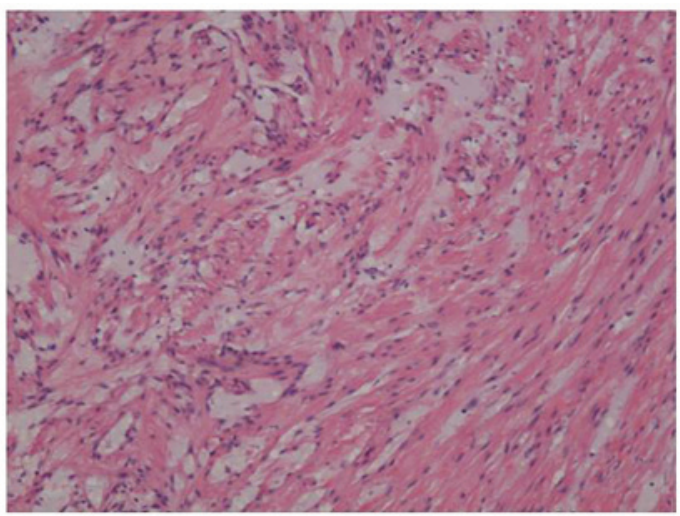

Figure 1. Histopathology of resected tumor tissue. Histopathological analysis identified crossing bundles of blunt-ended tumoral cells containing homogeneous eosinophilic acellular areas. Furthermore, the benign tumor was composed of sheets and fascicles of oval and spindle-shaped cells with abundant, dense cytoplasm. The atypia of granular chromatin is non-significant. Karyokinesis was not observed. Staining, hematoxylin and eosin; magnification, x100.

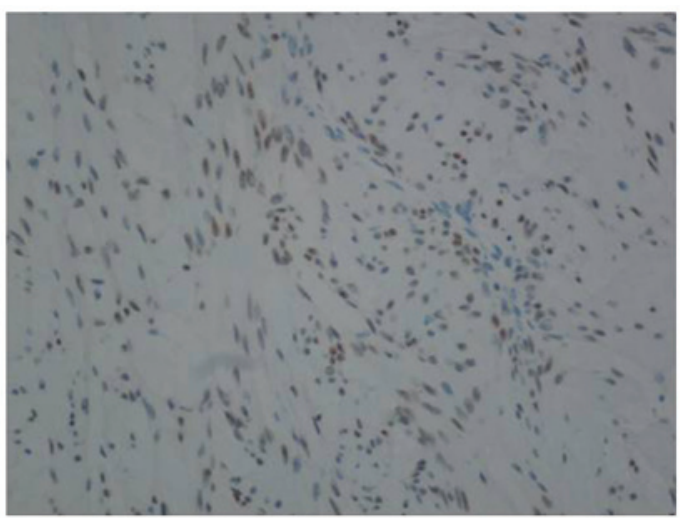

Figure 2. Immunohistochemical ER staining. ER expression was localized to the nucleus. Expression was evaluated semi-quantitatively, taking into account the proportion of positive cell nuclei and the intensity of the reaction. The degree of positive expression is $+2(40 \%)$. Magnification, $\mathrm{x} 100$. ER, estrogen receptor.

leiomyoma has been reported in a postmenopausal women by Celik et al (4), and 3 cases of perineal leiomyoma in premenopausal women have been reported (Table I). The 3 patients were

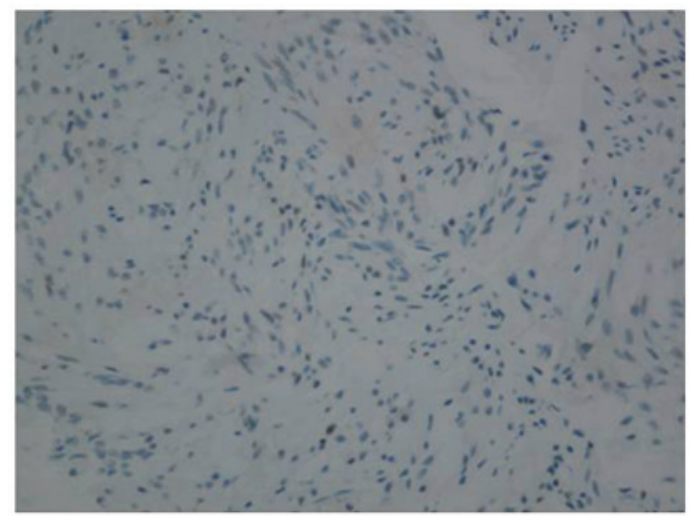

Figure 3. Immunohistochemical PR staining. PR expression should normally be localized to the nucleus; however, PR expression was negative in the resected tumor tissue. Magnification, x100.

all menstruating and $<50$ years old. To the best of our knowledge, no studies describing the continued growth of perineal leiomyomas in the postmenopausal period without hormone replacement therapy were reported in the literature.

The specific etiology of leiomyoma remains unknown. For uterine leiomyomas, the expression of PR and ER is usually positive, and estrogen- and progesterone-induced tumor growth is accepted as the likely cause (5). The expression of PR in leiomyomas is significantly higher than that of ER, regardless of menstrual cycle phase (6). In the present case, the patient was postmenopausal, and although ER expression was positive, the role of estrogen cannot be over emphasized as estrogen levels are significantly lower in postmenopausal women compared with premenopausal women (7). It has been reported that other possible factors underlying the development of these lesions may include stress, infection, and environmental and dietary factors (8). Infection may result in oncogenesis due to subsequent injury and/or inflammation resulting in cell proliferation, increased extracellular matrix and reduced apoptosis, apropos of abnormal tissue repair $(9,10)$. A number of molecular researchers presented a model depicting myoma development based on an abnormal response to tissue repair, resulting in formation of an altered extracellular matrix and disordered healing (9). 
Nielsen et al (11) studied 25 cases of vulval leiomyoma and observed that the primary symptom is a painless mass, with less common symptoms including pain, itching and erythema. Two of the masses described in Table I are soft and cystic, while the other is solid. One case presented with perineal tenderness and local pain following a right-sided mediolateral episiotomy, which occurred 1 year previously (1). However, in the current case, the patient presented with a painful and solid mass associated with lumbosacral radiating pain, the combination of which, to the best of our knowledge, has not yet been reported in any extensive review of the literature. The authors propose that the pain experienced by the current patient may be due to the lesion stimulating peripheral nerves. However, unanswered questions remain regarding the factors that induce leiomyoma development in postmenopausal women.

Leiomyomas of the vulva typically present with three different histological patterns: i) Spindled; ii) epithelioid; and iii) myxohyaline, which may be mixed or pure (12). The myxohyaline pattern is commonly associated with the epithelioid pattern, and a combination of spindle and epithelioid cells is often observed (11). The tumor in the present case was a benign, epithelioid perineal leiomyoma and did not exhibit any myxoid changes. Recurrence is extremely rare (13) and close follow-up is seldom required.

In conclusion, leiomyomas of the perineal occur most commonly in the fourth and fifth decades of life (11). The most common principle action of perineal leiomyoma is a painless mass $(4,14,15)$. Before a preoperative diagnosis, endoscopic ultrasound and MRI are suggested to be taken to aid differential diagnosis from Bartholin cysts, aggressive angiomyxoma. Perineal leiomyomas, exhibit three principal histological patterns-spindled, epithelioid and myxoid (12). Spindled is the most common. The excision of perineal leiomyomas is the most useful surgical option to cure leiomyomas completely $(4,11,16,17)$. Though the recurrence is uncommon, a short-time follow-up is still suggested.

\section{Acknowledgements}

The authors would like to thank Mrs. Hui-ting Liu from the First Affiliated Hospital, Xi'an Jiaotong University (Xi'an, China), for grammatically revising the original manuscript.

\section{References}

1. Oliveira Brito LG, Falcão Motoki L, Magnani PS, Sabino-de-Freitas MM, et al: Giant perineal leiomyoma incidentally manifested at a recent episiotomy site: Case report. J Minim Invasive Gynecol 18: 267-269, 2011

2. Massart F, Becherini L, Marini F, Noci I, Piciocchi L, Del Monte F, Masi L, Falchetti A, Tanini A, Scarselli G and Brandi L: Analysis of estrogen receptor (ERalpha and ERbeta) and progesterone receptor $(\mathrm{PR})$ polymorphisms in uterine leiomyomas. Med Sci Monit 9: BR25-BR30, 2003.

3. Pandey D, Shetty J, Saxena A and Srilatha PS: Leiomyoma in vulva: A diagnostic dilemma. Case Rep Obstet Gynecol 2014: 386432, 2014.

4. Celik H, Bildircin FD, Kefeli M, Yavuz E and Kokcu A: Labial leiomyoma growing gradually in the vulva of an elderly woman. J Obstet Gynaecol 32: 816, 2012.

5. Reyad MM, Gazvani MR and Khine MM: A rare case of primary leiomyoma of the vulva. J Obstet Gynaecol 26: 73-74, 2006.

6. Zasławski R, Surowiak P, Dziegiel P, Pretnik L and Zabel M: Analysis of the expression of estrogen and progesteron receptors, and of PCNA and Ki67 proliferation antigens, in uterine myomata cells in relation to the phase of the menstrual cycle. Med Sci Monit 7: 908-913, 2001.

7. Unfer TC, Figueiredo CG, Zanchi MM, Maurer LH, Kemerich DM, Duarte MM, et al: Estrogen plus progestin increase superoxide dismutase and total antioxidant capacity in postmenopausal women. Climacteric 18: 379-388, 2015.

8. Khan AT, Shehmar M and Gupta JK: Uterine fibroids: Current perspectives. Int J Womens Health 6: 95-114, 2014.

9. Leppert PC, Catherino WH and Segars JH: A new hypothesis about the origin of uterine fibroids based on gene expression profiling with microarrays. Am J Obstet Gynecol 195: 415-420, 2006.

10. Rogers R, Norian J, Malik M, Christman G, Abu-Asab M, Chen F, Korecki C, Iatridis J, Catherino WH, Tuan RS, et al: Mechanical homeostasis is altered in uterine leiomyoma. Am J Obstet Gynecol 198: 474.e1-e11, 2008.

11. Nielsen GP, Rosenberg AE, Koerner FC, Young RH and Scully RE: Smooth-muscle tumors of the vulva. A clinicopathological study of 25 cases and review of the literature. Am J Surg Pathol 20: 779-793, 1996.

12. Nucci MR and Fletcher CD: Vulvovaginal soft tissue tumours: Update and review. Histopathology 36: 97-108, 2000.

13. Goyal LD, Kaur H, Kaur K and Kaur S: An unusual case of vaginal myoma presenting with postmenopausal bleeding. J Family Reprod Health 7: 103-104, 2013.

14. Roy KK, Mittal S and Kriplani A: A rare case of vulval and perineal leiomyoma. Acta Obstet Gynecol Scand 77: 356-357, 1998.

15. Koc O, Sengul N and Gurel S: Perineal leiomyoma mimicking complex Bartholin mass. Int Urogynecol J 21: 495-497, 2010.

16. Newman PL and Fletcher CD: Smooth muscle tumours of the external genitalia: clinicopathological analysis of a series. Histopathology 18: 523-529, 1991.

17. Ngo Q and Haertsch P: Vulvar leiomyoma in association with gastrointestinal leiomyoma. Aust N Z J Obstet Gynaecol 51: 468-469, 2011. 